\title{
PENGARUH INTERAKSI VIRTUAL DAN EKUITAS MEREK NEX CARLOS TERHADAP MINAT BELI PENGIKUT DI INSTAGRAM
}

\author{
Jeremiah Purna Wijaya ${ }^{1}$, Natasya Yemima Ongkosuwito ${ }^{2}$, Regina Jokom ${ }^{3 *}$ \\ 1,2,3 Program Manajemen Perhotelan, Program Studi Manajemen, Fakultas Bisnis dan Ekonomi, \\ Universitas Kristen Petra, Jl. Siwalankerto 121-131, Surabaya, Indonesia \\ Email: 1jeremiahjpw@gmail.com; 'natasyayemima@gmail.com; ${ }^{3}$ regina@petra.ac.id \\ *Penulis Korespondensi
}

\begin{abstract}
Abstrak
Nex Carlos adalah salah satu selebriti endorser yang populer di Indonesia yang terkenal dengan konten makanannya. Penelitian ini dilakukan untuk mengetahui seberapa besar tingkat pengaruh Interaksi Virtual dan Ekuitas Merek (kesadaran merek, citra merek, dan loyalitas merek) Nex Carlos terhadap minat beli pengikutnya di Instagram. Data penelitian didapat dengan melakukan survei kepada 218 pengikut akun Instagram Nex Carlos. Teknik Analisa data yang dugunakan adalah Partial Least Square. Hasil penelitian menunjukkan bahwa interaksi virtual dan ekuitas merek Nex Carlos berpengaruh secara positif dan signifikan terhadap minat beli pengikutnya di Instagram.
\end{abstract}

Kata kunci: Interaksi Virtual; Ekuitas Merek; Minat Beli; Instagram; Nex Carlos.

\begin{abstract}
Nex Carlos is one of celebrity endorsers in Indonesia, who is getting popular with food review as his content. This research was conducted to determine the impact of virtual interactivity and brand equity (brand awareness, brand image, and brand loyalty) of Nex Carlos to the followers purchase intention on Instagram. The Data was gathered by conducting survey to 218 Nex Carlos Instagram account followers. This research uses Partial Least Square as a data analysis technique. The result of the research shows that virtual interactivity and brand equity of Nex Carlos has a positively and significant impact to the followers purchase intention on Instagram.
\end{abstract}

Keywords: Virtual Interactivity; Brand Equity, Purchase Intention; Instagram; Nex Carlos.

\section{PENDAHULUAN}

Semakin banyaknya selebgram yang muncul, membuat seorang selebgram harus memiliki keunikan sendiri yang menjadi pembeda dengan selebgram lainnya. Karena itu, selebgram harus mempunyai human brand yang kuat. Human brand mengarah kepada semua orang yang terkenal dan menjadi subjek pemasaran yang berfungsi sebagai salah satu aset termasuk reputasi sosial, citra, atau kredibilitasnya. Selebriti sekarang dikonseptualisasikan sebagai human brand (Thomson, 2006). Melalui penelitian yang dilakukan oleh Osorio et al. (2020) menyatakan bahwa hasil dari pembentukan human brand yang kuat adalah timbulnya ekuitas merek.

Salah satu faktor yang mendukung dalam membentuk kekuatan merek seorang selebgram adalah melalui interaksi virtual (Liu, Zhang, \& Zhang, 2020). Interaksi virtual adalah interaksi antara selebgram dengan pengikutnya secara virtual. Sukhdial et al. (2002) menyatakan bahwa selebgram dapat dengan efektif menjangkau konsumen jika ada hubungan yang tercipta dengan para pengikut dan ada interaksi yang dibangun. Dengan adanya media sosial Instagram, para selebriti dapat berinteraksi dengan pengikutnya dengan mudah.

Untuk mengukur kekuatan merek seseorang, peneliti menggunakan konsep ekuitas merek. Secara umum teori ekuitas merek dari Keller (1993) menyatakan bahwa ekuitas merek terdiri dari 4 dimensi, yakni kesadaran merek, citra merek, persepsi kualitas, dan loyalitas merek. Dalam konteks human brand, peneliti mengacu pada penelitian Liu, Zhang \& Zhang (2020) yang menggunakan 3 dimensi yaitu kesadaran merek, citra merek, dan loyalitas merek. Dimensi persepsi kualitas tidak digunakan karena dimensi ini dinilai sama seperti konsep citra merek dalam konteks human brand. (Liu, Zhang \& Zhang, 2020). Kesadaran merek artinya adalah kesanggupan konsumen untuk mengenali atau mengingat kembali suatu nama merek (Aaker, 2009). Kesadaran terhadap seorang selebgram dapat diketahui bila pengikutnya dapat mengenali dan mengingat selebgram tersebut.

Setelah kesadaran dari seorang selebgram terbentuk, maka citra dari selebriti tersebut akan terbentuk di ingatan para pengikutnya. Doyle (2009) 
mengatakan bahwa citra adalah bagaimana pasar memandang atau melihat karakter suatu merek (Asosiasi merek). Asosiasi merek adalah segala sesuatu yang melekat pada pikiran atas sebuah merek (Aaker, 2009). Keller (1993) menyatakan bahwa asosiasi merek sama seperti citra merek. Citra merek melibatkan persepsi masyarakat mengenai sebuah merek, yang merupakan kumpulan dari asosiasi merek yang terbentuk di pikiran masyarakat. Citra merek yang dimiliki seseorang berarti persepsi seseorang kepada orang lain yang didapatkan dari perilaku, latar belakang, masa lalu, karakter, dan lain-lain yang dimiliki seseorang.

Setelah para pengikut dari seorang selebgram mengenal dan mempunyai persepsi yang positif kepada selebgram yang diikuti maka akan terbentuk loyalitas terhadap selebgram yang diikuti. Seperti para pengikutnya akan lebih sering melihat konten yang dibuat oleh selebgram tersebut. Dengan adanya loyalitas dalam mengikuti selebgram tersebut, maka jika selebgram mengiklankan suatu produk atau merek, maka pengikutnya juga akan tertarik untuk mencoba dan membeli produk tersebut, hal ini disebut dengan minat beli.

Penelitian ini dilakukan dengan menggunakan subjek celebrity endorser yang berkecimpung di dunia food blogger yaitu Nex Carlos. Nex Carlos adalah content creator makanan yang telah mempunyai 3,35 juta subscribers di YouTube dan juga 886.000 pengikut di Instagram (bulan Desember 2020). Peneliti memilih Nex Carlos menjadi subjek penelitian dikarenakan Nex Carlos adalah food blogger yang menempati posisi kedua terbesar di Indonesia (Firmansyah, 2020). Dan termasuk selebgram yang sering berinteraksi dengan pengikutnya melalui fiturfitur yang ada di Instagram.

Penelitian ini merupakan adaptasi dari penelitian Liu, Zhang \& Zhang (2020). Dan masih sangat jarang ditemukan penelitian yang membahas secara mendalam mengenai hal ini, khususnya di Indonesia, masih belum ditemukan penelitian yang menggali secara mendalam mengenai merek dari selebriti itu sendiri yang diukur melalui interaksi virtual selebriti. Maka dari itu, peneliti ingin meneliti mengenai pengaruh interaksi virtual dan ekuitas merek yang dimiliki Nex Carlos terhadap minat beli pengikut Instagramnya di Indonesia.

\section{TINJAUAN PUSTAKA}

\section{Interaksi Virtual}

Dalam komunikasi pemasaran, interaksi virtual dapat digolongkan sebagai pemasaran interaktif, yaitu aktivitas daring dan program yang dirancang untuk menjangkau konsumen, yang dapat meningkatkan kesadaran merek, dan citra merek dari perusahaan tersebut (Keller,2009). Oleh karena itu, tidak sedikit perusahaan yang mulai menggunakan selebriti online untuk memasarkan produknya. Karena selebriti online dapat membangun interaksi virtual secara langsung dengan para pengikutnya. Sosial media seperti Facebook dan Instagram digunakan oleh selebriti online untuk membangun hubungan yang kuat dengan para pengikutnya. Hubungan yang terbentuk ini terbentuk melalui interaksi secara virtual. (Hwang \& Zhang, 2018) Interaksi virtual dapat digolongkan sebagai interaksi daring antara sesama manusia. Interaksi virtual digambarkan dengan komunikasi 2 arah antara selebgram dengan pengikutnya melalui comment dan feedback pada sosial media selebriti tersebut (Jun \& Yi, 2019). Interaksi dari seorang selebriti dapat menuntun pengikut-pengikutnya untuk mempunyai koneksi emosional terhadap merek yang dipromosikan oleh selebriti tersebut (Jun \& Yi, 2019). Demir (2010) menyatakan bahwa frekuensi interaksi adalah salah satu elemen penting dari dimensi interaksi. Interaksi virtual yang dilakukan secara berulang-ulang juga adalah salah satu kunci untuk membangun kepercayaan dari konsumen (Wang \& Emurian, 2005). Keragaman interaksi ditunjukkan melalui konten seorang selebgram yang kreatif, bisa melalui foto, video, atau bahkan musik (Liu, Zhang \& Zhang, 2020).

\section{Ekuitas Merek}

Ekuitas merek adalah serangkaian aset dan liabilitas dari sebuah merek yang terkait dengan nama dan simbol dari merek tersebut, yang dapat menambah atau mengurangi nilai yang diberikan produk atau jasa kepada perusahaan atau pada konsumen (Aaker, 1995). Secara umum, Keller (1993) menyatakan bahwa yang membentuk ekuitas merek terdiri dari 4 konsep, yaitu kesadaran merek, citra merek, perceived quality, dan loyalitas merek. Peneliti mengacu pada penelitian Liu, Zhang \& Zhang yang menggunakan 3 konsep yaitu kesadaran merek, citra merek, dan loyalitas merek. Konsep perceived quality tidak digunakan karena menurut penelitian Liu, Zhang \& Zhang (2020), konsep tersebut lebih mengarah kepada aspek fungsional dari sebuah produk dan kurang sesuai untuk penelitian yang membahas tentang human brand. Jika ingin mengukur "kualitas" yang dimiliki seseorang, pasti akan menyorot pada karakter yang dimiliki orang tersebut. Oleh karena itu konsep perceived quality dinilai sama dengan konsep citra 
merek dalam konteks human brand. Untuk membangun human brand seseorang dapat digunakan konsep ekuitas merek, karena konsep ekuitas merek tidak hanya dapat digunakan untuk produk/jasa saja. Membangun merek seseorang sama dengan membangun reputasi seseorang dengan menggunakan konsep ekuitas. Dengan adanya sosial media dan perkembangan teknologi membuat setiap informasi yang disodorkan seseorang ke orang lain menjadi faktor pembentuk merek yang dimiliki seseorang yang menimbulkan adanya perbedaan antara sesama manusia. (Vitberg, 2010)

\section{Interaksi Virtual dan Kesadaran Merek}

Selebgram dapat menjangkau lebih banyak lagi masyarakat dengan membangun interaksi dengan pengikutnya secara konsisten. Semakin sering selebgram update atau berinteraksi maka akan semakin sering selebgram tersebut muncul di Instagram explore, maka selebgram tersebut dapat menjangkau masyarakat yang lebih luas agar dapat meningkatkan kesadaran akan selebriti tersebut. Menurut (Barreda et al., 2016) interaksi virtual dapat membantu sebuah merek untuk membuat konsumen mengetahui (aware) dan mengenal tentang karakteristik merek tersebut. Jadi interaksi virtual dapat membantu konsumen mengenal atau mengetahui seorang selebgram. Dari pernyataan tersebut dapat dibuat hipotesa sebagai berikut:

H1: Interaksi virtual dapat mempengaruhi secara positif dan signifikan terhadap kesadaran pengikut Nex Carlos.

\section{Interaksi Virtual dan Citra Merek}

Interaksi virtual digambarkan dengan komunikasi 2 arah antara selebgram dengan pengikutnya melalui pemberikan komentar pada sosial media selebriti tersebut (Jun \& Yi, 2019). Dengan adanya interaksi yang terbentuk antara selebriti dan pengikutnya, maka pengikut akan mempunyai kesan terhadap selebriti tersebut. Seperti karakter selebriti tersebut, atau ciri-ciri selebriti tersebut, dengan adanya asosiasi merek yang dipunyai konsumen, akan timbul citra merek kepada selebriti tersebut. Aaker (1997) menyatakan bahwa sebuah kumpulan karakteristik manusiawi yang terikat dengan sebuah merek dapat disebut sebagai citra. Semakin sering interaksi antara selebriti dan pengikutnya terbentuk, maka karakter selebriti tersebut akan tergambar pada pikiran para pengikutnya dan citra dari selebriti tersebut akan terbentuk. Dari pernyataan tersebut maka dapat dibuat hipotesa sebagai berikut:
H2: Interaksi virtual dapat mempengaruhi secara positif dan signifikan terhadap citra merek Nex Carlos.

\section{Kesadaran Merek dan Citra Merek}

Kesadaran akan seorang selebgram dapat diketahui bila pengikutnya dapat mengenali dan mengingat selebgram tersebut. Setelah kesadaran dari seorang selebgram terbentuk, maka citra dari selebriti tersebut akan terbentuk di ingatan para pengikutnya. Kesadaran merek adalah faktor penting pembentuk citra merek. Setelah konsumen mengenal merek tersebut, konsumen baru dapat membentuk citra yang positif akan merek tersebut (Keller, 1993). Dari penelitian yang dilakukan Manthiou et al. (2014) membuktikan dalam konteks sosial media, kesadaran merek memberi dampak signifikan terhadap citra merek. Dari pernyataan tersebut dapat dibentuk hipotesa sebagai berikut:

H3: Kesadaran pengikut Nex Carlos dapat mempengaruhi secara positif dan signifikan terhadap citra merek Nex Carlos.

\section{Kesadaran Merek dan Loyalitas Merek}

Setelah mempunyai kesadaran akan selebriti, pengikut mulai mengenal selebriti tersebut dan mengikuti akun Instagram selebriti. Karena itu, pengikut mulai mengikuti setiap update yang diberikan selebriti lewat Instagram, dan mengikuti setiap konten yang dibuat oleh selebriti. Adanya fitur dari Instagram dapat mempermudah pengikut untuk mengikuti setiap keseharian selebriti. Dari adanya kesadaran akan selebriti membuat pengikut akan mempunyai loyalitas kepada selebriti yang diikuti. (Liu, Zhang \& Zhang, 2020) Dari pernyataan tersebut dapat dibentuk hipotesa sebagai berikut:

H4: Kesadaran pengikut Nex Carlos dapat mempengaruhi secara positif dan signifikan terhadap loyalitas pengikut Nex Carlos.

\section{Citra Merek dan Loyalitas Merek}

Citra positif yang melekat pada seorang selebriti dapat membuat para pengikutnya akan lebih sering melihat konten yang dibuat oleh selebgram tersebut. Dengan adanya fitur Instagram seperti Instagram story, live, post dan sebagainya membuat masyarakat dapat mengikuti keseharian selebgram yang diikuti. Dari hal tersebut akan terbentuk loyalitas kepada selebgram tersebut. Maka dari pernyataan tersebut dapat dibuat hipotesa sebagai berikut: 
H5: Citra merek yang positif dapat mempengaruhi secara positif dan signifikan terhadap loyalitas pengikut Nex Carlos.

\section{Loyalitas Merek dan Minat Beli}

Schiffman et al. (2012) mengatakan bahwa bagi konsumen selebriti online adalah seseorang yang memberikan referensi mengenai produk atau jasa agar dapat membantu konsumen menentukan keputusan pembelian. Saat selebgram dijadikan referensi saat ingin menentukan keputusan pembelian, maka dibutuhkan selebgram yang terpercaya. Dengan adanya lebih banyak masyarakat yang mengapresiasi seorang selebriti, dan banyaknya pengikut yang mempunyai loyalitas terhadap selebriti tersebut akan membuat selebriti tersebut dapat lebih dipercaya (Fleck et al, 2012). Dengan adanya kepercayaan tersebut, konsumen akan dengan mudah melakukan pembelian suatu produk atau jasa yang direkomendasikan selebgram tersebut. Maka hipotesa yang dapat dibentuk adalah sebagai berikut:

H6: Loyalitas pengikut dapat mempengaruhi secara positif dan signifikan terhadap minat beli pengikut Nex Carlos.

\section{METODE PENELITIAN}

Penelitian ini merupakan penelitian kausal dimana ingin meneliti hubungan antar variabel yakni, interaksi virtual, kesadaran merek, citra merek, loyalitas merek, dan minat beli. Populasi dalam penelitian ini adalah pengikut Instagram dari seorang selebgram dan food blogger yaitu Nex Carlos. Survei dilakukan melalui Instagram kepada 218 responden yang dianggap memenuhi syarat sesuai dengan kriteria sampel yang telah ditentukan, yakni pengikut dari Nex Carlos, usia minimal 17 tahun, dan aktif membuka Instagram setiap hari.

Kuesioner berisi 7 bagian yang terdiri dari profil responden, perilaku menggunakan instagram, pengukuran interaksi virtual, pengukuran kesadaran merek, pengukuran citra merek, pengukuran loyalitas merek, dan pengukuran minat beli. Interaksi virtual diukur dengan 9 indikator yang diadaptasi dari Liu, Zhang \& Zhang (2020) dan Jun \& Yi (2020), sedangkan 3 indikator kesadaran merek diadaptasi dari Liu, Zhang \& Zhang (2020) dan Park (2019). Selain itu, citra merek diukur dengan 3 indikator yang diadaptasi dari Liu, Zhang \& Zhang (2020), loyalitas merek diukur dengan 5 indikator yang dari Liu, Zhang \& Zhang (2020), Jun \& Yi (2020), dan Park (2019). Kemudian, minat beli memiliki 3 indikator yang diadaptasi dari Liu, Zhang \& Zhang (2020) dan Jalilvand \& Samiei (2012). Pengukuran dilakukan dengan menggunakan 5 skala Likert mulai dari sangat tidak setuju (1) hingga sangat setuju (5)

Sebelum pengumpulan data dilakukan pilot study kepada 30 responden yang diuji validitas dan reliabilitas dengan pearson correlation dimana nilai signifikansi tidak lebih dari 0.05 dan Cronbach's Alpha lebih dari 0.6. Data yang terkumpul sebanyak 218 responden kemudian dianalisa menggunakan metode Partial Least Square (PLS).

\section{HASIL PENELITIAN DAN PEMBAHASAN}

\section{Profil Responden}

Dalam penelitian ini, sebanyak 218 responden dinyatakan telah memenuhi syarat kriteria sebagai sampel penelitian. Profil responden diolah seperti pada Tabel 1.

Berdasarkan tabel 1 dapat diketahui bahwa mayoritas responden adalah pelajar laki-laki berusia 17-25 tahun. Responden dalam penelitian ini termasuk responden yang aktif dalam memakai Instagram, diketahui rata-rata waktu yang dipakai untuk menggunakan Instagram adalah 1-3 jam. Mayoritas konten yang paling sering dilihat oleh responden di Instagram adalah konten kuliner (makanan dan minuman). Dan rata-rata responden dalam keseringan membuka profil akun Instagram Nex Carlos (@nexcarlos) adalah 1-2 hari dalam 1 minggu.

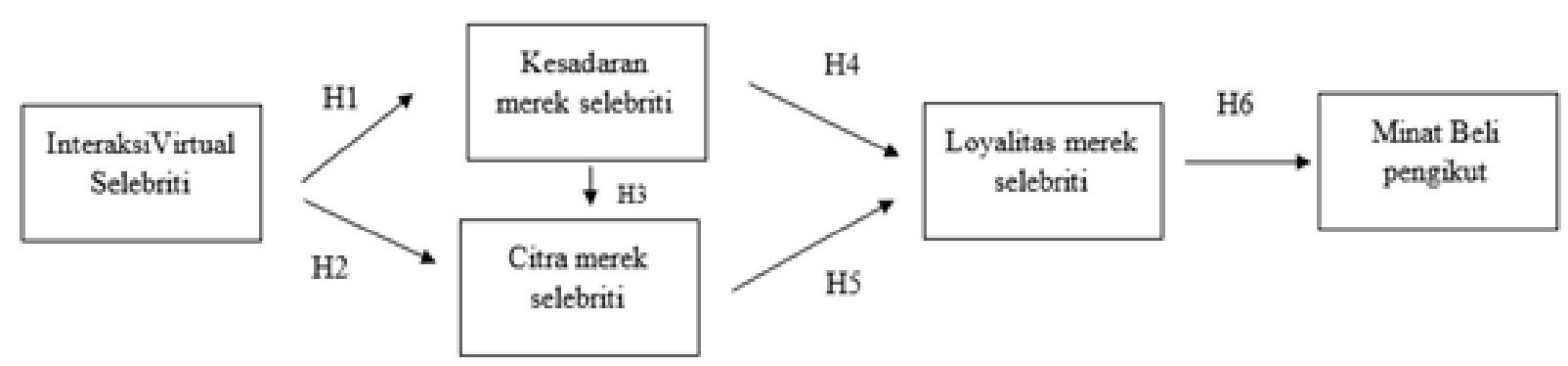

Gambar 1. Model Penelitian 
Tabel 1. Profil Responden

\begin{tabular}{|c|c|c|c|}
\hline No & Keterangan & $\mathbf{n}$ & $\%$ \\
\hline 1 & $\begin{array}{l}\text { Jenis Kelamin: } \\
\text { - Laki-Laki } \\
\text { - Perempuan }\end{array}$ & $\begin{array}{c}128 \\
90 \\
\end{array}$ & $\begin{array}{l}58.7 \% \\
41.3 \% \\
\end{array}$ \\
\hline 2 & $\begin{array}{l}\text { Pekerjaan: } \\
\text { - Pelajar/Mahasiswa } \\
\text { - Wiraswasta } \\
\text { - Karyawan Swasta } \\
\text { - Pegawai Negeri } \\
\text { - Profesional (Dokter, } \\
\quad \text { Pengacara, dll) } \\
\text { - Ibu Rumah Tangga } \\
\text { - Pensiunan } \\
\text { - Lainnya }\end{array}$ & $\begin{array}{c}115 \\
30 \\
40 \\
12 \\
5 \\
12 \\
0 \\
4\end{array}$ & $\begin{array}{c}52.8 \% \\
13.8 \% \\
18.3 \% \\
5.5 \% \\
2.3 \% \\
5.5 \% \\
0 \% \\
1.8 \%\end{array}$ \\
\hline 3 & $\begin{array}{l}\text { Usia: } \\
\text { - 17-25 tahun } \\
\text { - 26-35 tahun } \\
\text { - 36-40 tahun } \\
\text { - 41-45 tahun } \\
\text { - Lebih dari } 45 \text { tahun } \\
\end{array}$ & $\begin{array}{c}152 \\
49 \\
11 \\
5 \\
1 \\
\end{array}$ & $\begin{array}{c}69.7 \% \\
22.5 \% \\
5 \% \\
2.3 \% \\
0.5 \% \\
\end{array}$ \\
\hline 4 & $\begin{array}{l}\text { Rata- rata waktu yang } \\
\text { dihabiskan untuk membuka } \\
\text { Instagram dalam sehari: } \\
\text { - Kurang dari } 1 \text { jam } \\
\text { - 1-3 jam } \\
\text { - 4-6 jam } \\
\text { - Lebih dari } 6 \text { jam } \\
\end{array}$ & $\begin{array}{c}27 \\
142 \\
32 \\
17\end{array}$ & $\begin{array}{l}12.4 \% \\
65.1 \% \\
14.7 \% \\
7.8 \%\end{array}$ \\
\hline 5 & $\begin{array}{l}\text { Konten yang paling sering } \\
\text { dilihat: } \\
\text { - Kuliner } \\
\text { - Gaya hidup } \\
\text { - Fesyen } \\
\text { - Berita } \\
\text { - Lainnya }\end{array}$ & $\begin{array}{c}113 \\
58 \\
23 \\
14 \\
10\end{array}$ & $\begin{array}{c}51.8 \% \\
26.6 \\
10.6 \% \\
6.4 \% \\
4.6 \%\end{array}$ \\
\hline 6 & $\begin{array}{l}\text { Keseringan dalam melihat } \\
\text { profil akun Instagram Nex } \\
\text { Carlos (@nexcarlos) dalam } \\
1 \text { minggu: } \\
\text { - 1-2 hari } \\
\text { - 3-4 hari } \\
\text { - 5-6 hari } \\
\text { - Setiap hari } \\
\end{array}$ & $\begin{array}{l}95 \\
83 \\
15 \\
25\end{array}$ & $\begin{array}{c}43.5 \% \\
38.1 \% \\
6.9 \% \\
11.5 \%\end{array}$ \\
\hline
\end{tabular}

\section{Pengujian Jalur}

Peneliti melihat nilai dari masing-masing outer loading untuk mengukur validitas konvergen. Sebuah indikator dapat dikatakan memenuhi validitas konvergen jika memiliki nilai outer loading $>0,5$.

Validitas diskriminan dinilai berdasarkan nilai cross loading dengan variabelnya. Indikator dianggap memenuhi syarat jika nilai korelasi antar indikator dengan variabel aslinya lebih besar. Dapat dikatakan bahwa semua indikator memenuhi syarat validitas diskriminan dimana nilai korelasi antar indikator dengan variabel aslinya lebih besar.
Selain itu, untuk menguji reliabilitas digunakan composite reliability dan cronbach's alpha. Composite reliability menguji nilai reliabilitas indikator-indikator pada suatu konstruk. Suatu konstruk atau variabel dikatakan memenuhi composite reliability jika memiliki nilai composite reliability lebih dari 0,7 (Solimun, Fernandes, \& Nurjannah, 2017). Suatu variabel dapat dikatakan reliabel jika memiliki nilai Cronbach's Alpha dari 0.6 (Solimun, Fernandes, \& Nurjannah, 2017). Hasil menunjukkan bahwa semua variabel reliabel karena telah memenuhi syarat.

Tabel 2. Hasil Composite Reliability dan Cronbach's Alpha

\begin{tabular}{lccc}
\hline & $\begin{array}{c}\text { Composite } \\
\text { Reliability }\end{array}$ & $\begin{array}{c}\text { Cronbach's } \\
\text { Alpha }\end{array}$ & $\begin{array}{c}\text { AVE (Average } \\
\text { Variance } \\
\text { Extracted) }\end{array}$ \\
\hline Interaksi Virtual & 0,883 & 0,845 & 0.463 \\
Kesadaran Merek & 0,855 & 0,746 & 0.664 \\
Citra Merek & 0,862 & 0,761 & 0.676 \\
Loyalitas Merek & 0,861 & 0,801 & 0.556 \\
Minat Beli & 0,883 & 0,802 & 0.717 \\
\hline
\end{tabular}

Nilai $\mathrm{R}^{2}$ digunakan untuk mengukur tingkat variasi perubahan atau seberapa besarnya pengaruh variabel independen terhadap variabel yang dependen. Hasil menunjukkan bahwa variabel kesadaran merek mempunyai nilai $\mathrm{R}^{2}$ sebesar 0.224 atau $22.4 \%$, variabel citra merek mempunyai nilai sebesar 0.378 atau $37.8 \%$, variabel loyalitas merek adalah 0.438 atau $43.8 \%$, dan variabel minat beli mempunyai nilai Rsquare sebesar 0.413 atau $41.3 \%$. Hal ini mengindikasikan bahwa model struktural dinilai sudah baik dalam mengukur variasi nilai dari variabel- variabel tersebut. Perhitungan $\mathrm{Q}^{2}$ digunakan untuk mengukur seberapa baik nilai observasi dihasilkan oleh model dan juga estimasi parameternya. Q2 $=1-(1-0.224)(1-$ $0.378)(1-0.438)(1-0.413)=0.841$. Hasil perhitungan $\mathrm{Q}^{2}$ diatas menunjukan angka $\mathrm{Q}^{2}$ yang lebih besar dari nol, yaitu 0.841 . Oleh karena itu, nilai $\mathrm{Q}^{2}$ sudah dapat dianggap memiliki prediksi relevansi atau layak untuk digunakan.

Hipotesis penelitian dapat diterima jika nilai thitung (t-statistik) lebih besar daripada t-tabel pada tingkat kesalahan 5\% yaitu 1.96 (two-tailed). Pengujian ini dilakukan untuk melihat besarnya pengaruh variabel interaksi virtual terhadap minat beli melalui kesadaran merek, citra merek, dan loyalitas merek sebagai variabel intervening. Peneliti melakukan pengujian hipotesis dengan menggunakan bootstrapping yang terdapat dalam software smartPLS. Berikut merupakan hasil uji yang diperoleh terlihat pada Tabel 3 . 


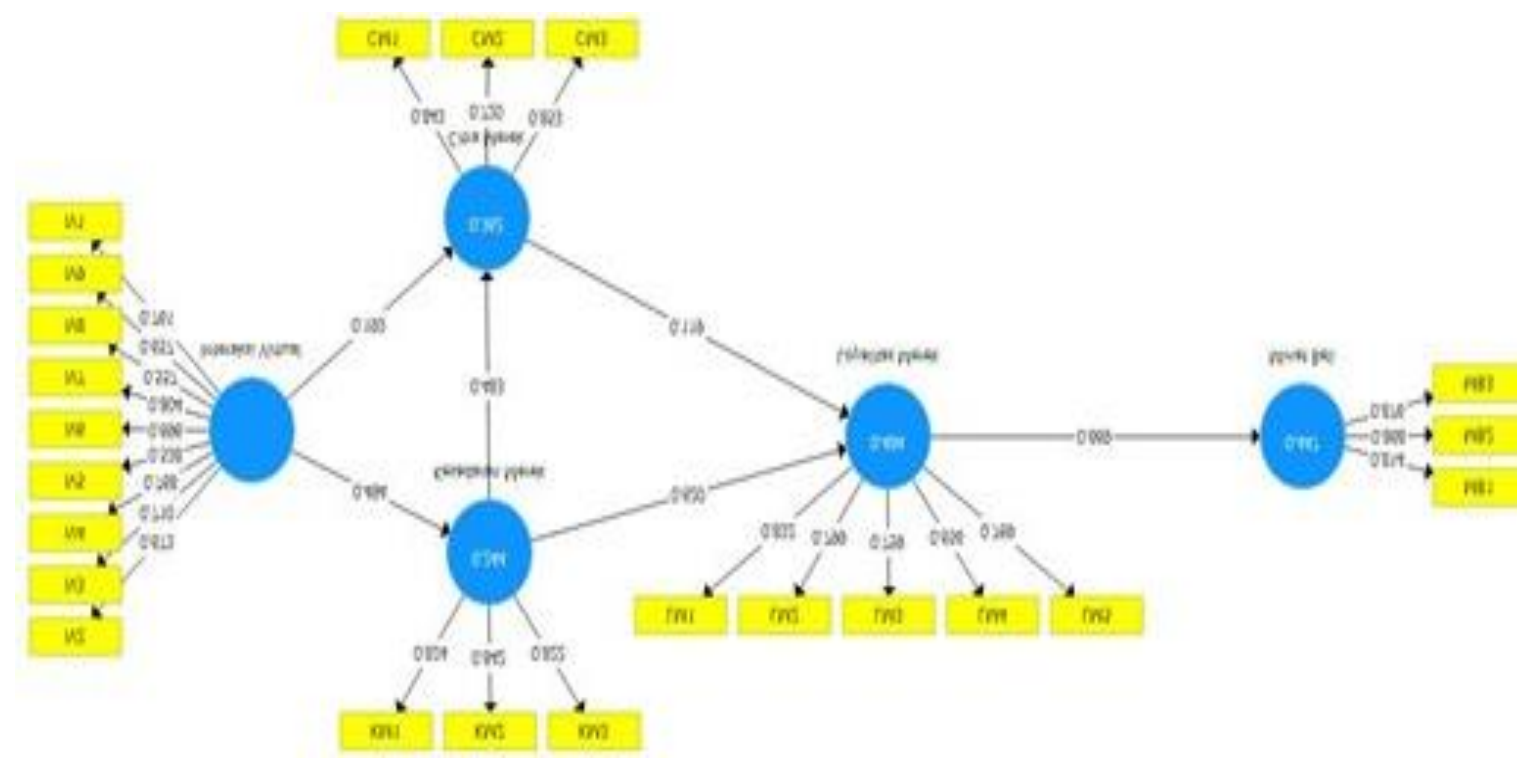

Gambar 2. Hasil Uji Validitas Konvergen

\begin{tabular}{|l|r|r|r|r|r|} 
& Citra Merek & Interaksi Virtual & Kesadaran Mer... & Loyalitas Merek & Minat Beli \\
\hline CM1 & 0.845 & 0.357 & 0.492 & 0.409 & 0.434 \\
\hline CM2 & 0.771 & 0.348 & 0.416 & 0.311 & 0.415 \\
\hline CM3 & 0.848 & 0.429 & 0.505 & 0.434 & 0.490 \\
\hline IV2 & 0.250 & 0.659 & 0.279 & 0.271 & 0.298 \\
\hline IV3 & 0.404 & 0.713 & 0.379 & 0.293 & 0.356 \\
\hline IV4 & 0.359 & 0.768 & 0.361 & 0.392 & 0.444 \\
\hline IV6 & 0.262 & 0.689 & 0.317 & 0.353 & 0.376 \\
\hline IV7 & 0.399 & 0.805 & 0.411 & 0.364 & 0.534 \\
\hline IV9 & 0.261 & 0.641 & 0.310 & 0.364 & 0.387 \\
\hline KM1 & 0.495 & 0.443 & 0.818 & 0.454 & 0.551 \\
\hline KM2 & 0.461 & 0.399 & 0.827 & 0.531 & 0.459 \\
\hline KM3 & 0.452 & 0.317 & 0.798 & 0.604 & 0.413 \\
\hline LM1 & 0.536 & 0.397 & 0.656 & 0.823 & 0.559 \\
\hline LM2 & 0.359 & 0.412 & 0.564 & 0.787 & 0.456 \\
\hline LM3 & 0.264 & 0.284 & 0.409 & 0.725 & 0.480 \\
\hline LM4 & 0.162 & 0.235 & 0.278 & 0.622 & 0.304 \\
\hline LM5 & 0.331 & 0.367 & 0.416 & 0.754 & 0.542 \\
\hline MB1 & 0.530 & 0.466 & 0.535 & 0.505 & 0.802 \\
\hline MB2 & 0.404 & 0.480 & 0.450 & 0.525 & 0.862 \\
\hline MB3 & 0.455 & 0.473 & 0.495 & 0.596 & 0.874 \\
\hline IV1 & 0.345 & 0.757 & 0.304 & 0.316 & 0.389 \\
\hline
\end{tabular}

Gambar 3. Cross Loading 
Tabel 3. Hasil Uji T

\begin{tabular}{|c|c|c|c|c|c|c|}
\hline Variabel ke Variabel & $\begin{array}{l}\text { Original } \\
\text { Sample }\end{array}$ & $\begin{array}{l}\text { Standar } \\
\text { Deviasi }\end{array}$ & t-table & t-hitung & Kesimpulan & Hipotesa \\
\hline 1 Interaksi Virtual ke Kesadaran Merek & 0.473 & 0.049 & 1.96 & 9.639 & (+) Signifikan & Diterima \\
\hline 2 Interaksi Virtual ke Citra Merek & 0.244 & 0.057 & 1.96 & 4.300 & (+) Signifikan & Diterima \\
\hline 3 Kesadaran Merek ke Citra Merek & 0.461 & 0.064 & 1.96 & 7.206 & (+) Signifikan & Diterima \\
\hline 4 Kesadaran Merek ke Loyalitas Merek & 0.567 & 0.058 & 1.96 & 9.695 & (+) Signifikan & Diterima \\
\hline 5 Citra Merek ke Loyalitas Merek & 0.146 & 0.055 & 1.96 & 2.636 & (+) Signifikan & Diterima \\
\hline 6 Loyalitas Merek ke Minat Beli & 0.642 & 0.037 & 1.96 & 17.379 & (+) Signifikan & Diterima \\
\hline
\end{tabular}

\section{Pengaruh Interaksi Virtual Terhadap Kesadaran Merek}

Hasil penelitian yang telah dilakukan menunjukkan adanya pengaruh antara variabel interaksi virtual terhadap kesadaran merek Nex Carlos. Peneliti mendapatkan hasil bahwa tingkat kecenderungan responden tinggi pada pernyataan bahwa responden akan mengingat Nex Carlos apabila responden ingin mencari informasi tentang kuliner. Dari hasil cross loading, indikator interaksi virtual yang paling berpengaruh terhadap variabel kesadaran merek adalah interaksi antara Nex Carlos dengan para pengikutnya sangat informatif dan bermanfaat bagi para pengikutnya. Berdasarkan hasil observasi peneliti, Nex Carlos memberikan informasi mengenai makanan yang masih jarang diketahui orang, dan juga Nex Carlos sering membagikan informasi mengenai alamat restoran, harga makanan, makanan rekomendasinya pada caption Instagram, Nex Carlos juga memberikan informasi tentang makanan tersebut yang cukup lengkap dengan bahasa yang luwes. Dengan adanya konten dan interaksi yang informatif dan bermanfaat dapat memicu kesadaran pengikut terhadap Nex Carlos. Karena saat pengikut membuka dan melihat akun Instagram Nex Carlos, jika konten dan interaksi yang dibuat informatif dan sesuai dengan kebutuhan dari para pengikutnya maka hal tersebut akan membuat para pengikutnya mengingat Nex Carlos apabila pengikutnya ingin mencari suatu informasi tentang kuliner (makanan dan minuman). Hal ini didukung oleh penelitian Liu, Zhang, \& Zhang (2020) yang menyatakan bahwa ada pengaruh yang signifikan antara interaksi virtual dengan kesadaran merek. Dengan demikian, hipotesis pertama yakni interaksi virtual berpengaruh positif dan signifikan terhadap kesadaran merek dapat diterima.

\section{Pengaruh Interaksi Virtual Terhadap Citra Merek}

Hasil penelitian yang telah dilakukan menunjukkan adanya pengaruh antara variabel interaksi virtual terhadap citra merek yang dimiliki oleh Nex Carlos.
Peneliti mendapatkan bahwa tingkat kecenderungan responden tinggi pada reputasi baik yang dimiliki Nex Carlos. Hasil tersebut didukung oleh hasil cross loading dimana indikator interaksi virtual yang paling mempengaruhi citra merek adalah ketika konten yang dibuat oleh Nex Carlos untuk berinteraksi dengan pengikutnya beragam. Dengan konten dan interaksi yang beragam mempermudah pengikut untuk mencari tahu informasi tentang Nex Carlos atau karakteristik yang dimiliki Nex Carlos. Salah satu contoh keberagaman konten yang dibuat Nex Carlos dapat dilihat dari QnA tentang kisah hidupnya yang ingin diketahui oleh pengikutnya, hobinya dalam bermain musik, konten berbagi kasih, dan masih banyak konten lainnya. Hal ini membuat para pengikutnya mempunyai kesan positif terhadap Nex Carlos sehingga pengikut memandang Nex Carlos sebagai selebgram yang mempunyai reputasi baik. Penelitian Liu, Zhang \& Zhang (2020) menyatakan bahwa interaksi virtual tidak berpengaruh secara signifikan terhadap citra merek, karena penelitian Liu, Zhang \& Zhang (2020) lebih berfokus pada frekuensi dan variasi media yang digunakan untuk berinteraksi. Sedangkan penelitian ini lebih mengarah kepada jenis konten dan keberagaman konten yang dibuat Nex Carlos. Dengan demikian, hipotesis kedua yaitu interaksi virtual berpengaruh positif dan signifikan terhadap citra merek dapat diterima.

\section{Pengaruh Kesadaran Merek Terhadap Citra Merek}

Hasil penelitian yang telah dilakukan menunjukkan adanya pengaruh antara variabel kesadaran merek terhadap citra merek yang dimiliki oleh Nex Carlos. Peneliti menemukan bahwa tingkat kecenderungan responden tinggi pada indikator bahwa Nex Carlos memiliki reputasi yang baik. Hasil tersebut didukung oleh nilai cross loading dimana yang paling mempengaruhi variabel citra merek dari variabel kesadaran merek adalah ketika pengikut dari Nex Carlos dapat dengan cepat mengingat ciri-ciri atau karakteristik yang dimiliki oleh Nex Carlos. Salah satu ciri- ciri yang 
dimiliki Nex Carlos adalah saat Nex Carlos mengulas makanan, ulasannya selalu informatif. Sehingga pengikut selalu mempunyai kesan bahwa Nex Carlos adalah selebgram yang mempunyai reputasi baik. Selain itu dapat dilihat pada akun Instagram Nex Carlos pada bulan Desember 2020 bahwa pengikut Nex Carlos sudah mencapai 886.000 pengikut, dengan 1.300 post. Hal ini dapat menjadi pemicu saat pengikut membuka akun Instagram Nex Carlos pertama kali, dapat menimbulkan kesan bahwa Nex Carlos adalah seorang selebgram yang mempunyai reputasi yang baik, dengan melihat jumlah pengikut di Instagram yang banyak, dan jumlah post, like, comment yang banyak. Hal ini didukung oleh penelitian Liu, Zhang, \& Zhang (2020) yang menyatakan bahwa ada pengaruh yang signifikan antara kesadaran merek dengan citra merek. Dengan demikian, hipotesis ketiga yaitu kesadaran merek berpengaruh positif dan signifikan terhadap citra merek dapat diterima.

\section{Pengaruh Kesadaran Merek Terhadap Loyalitas Merek}

Hasil menunjukkan bahwa kesadaran merek memiliki hubungan yang positif dan signifikan terhadap loyalitas pengikut Nex Carlos. Peneliti mendapat hasil bahwa responden cenderung tinggi pada pernyataan bahwa responden sering membagikan konten yang dibuat oleh Nex Carlos kepada orang lain. Dari uji cross loading yang dilakukan, didapati bahwa indikator kesadaran merek yang paling berpengaruh terhadap loyalitas merek adalah indikator apabila diminta menyebutkan salah satu selebgram yang mengulas tentang kuliner, Nex Carlos adalah selebgram yang pertama kali muncul di benak responden, dibanding selebgram lain. Profil responden pada penelitian ini cenderung sering mencari dan melihat konten kuliner. Dan sebesar 81,6\% dari responden pasti membuka akun Instagram Nex Carlos 1-4 hari dalam 1 minggu. Hal ini menunjukkan bahwa responden menjadikan Nex Carlos sebagai pilihan utama saat memikirkan selebgram yang mengulas kuliner. Dan dari data tersebut, menunjukkan bahwa dalam 1 minggu responden pasti melihat atau membuka konten yang dibuat Nex Carlos. Saat konten yang dibuat menarik dan informatif, besar kemungkinan responden akan membagikan konten tersebut pada orang lain. Hal ini menunjukkan bahwa pengikut Nex Carlos mempunyai loyalitas terhadap Nex Carlos dibanding selebgram lain karena yang diingat pertama kali adalah Nex Carlos dan dari banyaknya frekuensi pengikut dalam membagikan konten yang dibuat oleh Nex Carlos. Penelitian Liu, Zhang \& Zhang (2020) menyatakan bahwa kesadaran merek tidak berpengaruh secara signifikan pada loyalitas merek, karena penelitian Liu, Zhang \& Zhang (2020) menyatakan bahwa untuk membentuk loyalitas pada selebriti, selain pengikut mengingat selebriti tersebut, pengikut juga harus mengenal karakter selebriti tersebut. Namun pada penelitian ini, peneliti meneliti dalam konteks Instagram, dimana saat pengikut dapat dengan mudah memberikan like, comment, dan membagikan konten Nex Carlos kepada orang lain walaupun pengikut belum benar- benar mengenal karakter Nex Carlos. Oleh karena itu hipotesis keempat yakni kesadaran merek berpengaruh positif dan signifikan terhadap loyalitas merek dapat diterima.

\section{Pengaruh Citra Merek Terhadap Loyalitas Merek}

Hasil penelitian yang telah dilakukan menunjukkan adanya pengaruh antara variabel citra merek terhadap loyalitas merek yang dimiliki oleh Nex Carlos. Peneliti mendapatkan bahwa tingkat kecenderungan responden tinggi pada seringnya responden membagikan konten yang dibuat Nex Carlos. Hasil tersebut didukung oleh hasil cross loading dimana indikator citra merek yang paling mempengaruhi loyalitas merek adalah Nex Carlos merupakan selebgram yang dapat diandalkan karena memiliki pengetahuan kuliner yang luas. Nex Carlos terkenal dengan pengetahuannya yang luas tentang kuliner, hal ini dapat dilihat pada konten kuliner Nex Carlos yang informatif dan apa adanya, sehingga menjadikan Nex Carlos sebagai selebgram yang dapat diandalkan. Contohnya Nex Carlos dapat menggambarkan rasa dari makanan yang diulas, dengan menjelaskan cara memasak makanan tersebut, tekstur dari makanan tersebut, dan juga informasi yang perlu diketahui oleh pengikutnya. Hal ini menunjukkan bahwa Nex Carlos mempunyai pengetahuan yang luas seputar kuliner. Sehingga Nex Carlos adalah selebgram yang dapat diandalkan di mata para pengikutnya dan membuat pengikut Nex Carlos percaya pada setiap ulasan kuliner Nex Carlos, sehingga pengikut tidak ragu saat ingin membagikan konten yang dibuat Nex Carlos. Hal ini didukung oleh penelitian Liu, Zhang, \& Zhang (2020) yang menyatakan bahwa ada pengaruh yang signifikan antara citra merek dengan loyalitas merek. Dengan demikian hipotesis kelima yaitu citra merek berpengaruh secara positif dan signifikan terhadap loyalitas merek dapat diterima.

\section{Pengaruh Loyalitas Merek Terhadap Minat Beli}

Hasil menunjukkan bahwa loyalitas merek memiliki hubungan yang positif dan signifikan terhadap minat beli pengikut Nex Carlos. Peneliti mendapat hasil bahwa responden cenderung tinggi pada 
pernyataan bahwa setelah responden / melihat foto/ video kuliner yang diulas Nex Carlos di Instagram, responden berniat untuk membeli kuliner tersebut di masa yang akan datang. Hasil tersebut didukung oleh hasil cross loading dimana indikator loyalitas merek yang paling merefleksikan variabel minat beli adalah ketika pengikut merasa bahwa Nex Carlos akan menjadi pilihan utamanya saat pengikut mencari tahu sesuatu tentang ulasan kuliner di Instagram. Sehingga peneliti dapat menyimpulkan bahwa jika pengikut mempunyai kesetiaan terhadap Nex Carlos dan menjadikan Nex Carlos sebagai pilihan utama saat mencari informasi kuliner di Instagram, maka hal ini akan memunculkan minat beli pengikut terhadap kuliner yang diulas oleh Nex Carlos. Hal ini didukung oleh penelitian Liu, Zhang, \& Zhang (2020) yang menyatakan bahwa ada pengaruh yang signifikan antara loyalitas merek dengan minat beli. Oleh karena itu hipotesis keenam yaitu loyalitas merek berpengaruh positif dan signifikan terhadap minat beli dapat diterima.

\section{SIMPULAN DAN SARAN}

\section{Simpulan}

Berdasarkan hasil penelitian mengenai Pengaruh Interaksi Virtual dan Ekuitas Merek Nex Carlos Terhadap Minat Beli Pengikutnya di Instagram maka diperoleh hasil bahwa interaksi virtual dari Nex Carlos berpengaruh secara positif dan signifikan terhadap ekuitas merek yang dimiliki Nex Carlos dan berpengaruh secara positif dan signifikan juga terhadap minat beli pengikutnya di Instagram.

\section{Saran}

Hasil penelitian ini dapat menjadi masukkan untuk beberapa pihak, yaitu:

\section{Nex Carlos:}

Peneliti menyarankan Nex Carlos untuk membuat konten yang lebih informatif dan interaktif dari sebelumnya, seperti Instagram Live, polling, dan QnA lebih sering lagi. Peneliti juga menyarankan untuk Nex Carlos dapat berinteraksi secara langsung dengan pengikutnya sepeerti membalas komentar atau tanggapan pengikutnya agar pengikut dapat merasa seperti berkomunikasi secara langsung dengan Nex Carlos.

2. Pemilik bisnis kuliner:

Peneliti menyarankan agar pemilik bisnis kuliner yang ingin menggunakan jasa endorser dapat memilih endorser yang mempunyai ekuitas merek yang baik dalam mempromosikan produknya. Hal ini didukung oleh hasil penelitian yang menunjukkan bahwa ekuitas merek yang dimiliki selebriti berpengaruh secara positif dan signifikan terhadap minat beli pengikutnya.

3. Selebriti endorser:

Penelitian ini menunjukkan bahwa pentingnya seorang endorser dapat melakukan interaksi virtual dengan pengikutnya untuk membentuk ekuitas merek yang dimiliki selebriti tersebut. Dan juga selebriti endorser dapat membuat konten yang berkualitas karena hal ini sangat mempengaruhi ekuitas merek dari selebriti endorser tersebut.

4. Penelitian selanjutnya:

Untuk penelitian selanjutnya, variabel interaksi virtual dapat diubah dengan variabel sejenis lainnya seperti self-congruity, dan lainnya. Sehingga dapat mengetahui variabel apa saja yang dapat mempengaruhi ekuitas merek yang dimiliki oleh selebriti endorser. Metode penelitian yang digunakan juga dapat dirubah, misal dengan menggunakan pendekatan kualitatif yang mempertanyakan konten apa yang sebenarnya masyarakat sedang cari agar dapat membantu selebgram-selebgram maupun influencer yang ada.

\section{DAFTAR REFERENSI}

Aaker, D. A. (1995). Building Strong Brands. United States: The Free Press.

Aaker, J. L. (1997). Dimensions of brand personality. Journal of marketing research, 34(3), 347-356.

Aaker, D. A. (2009). Managing brand equity. United States: Simon and Schuster.

Activfans. (2020). 7 Tipe Selebgram Wajib di Follow di Indonesia. Retrieved Agustus 23, 2020, from https://activfans.com/7-tipe-selebgram-wajib-difollow-di-indonesia

Bauer, H. H., Sauer, N. E., \& Exler, S. (2005). The loyalty of German soccer fans: does a team's brand image matter?. International Journal of Sports Marketing \& Sponsorship, 7(1).

Doyle, P. (2009). Value-based marketing: marketing strategies for corporate growth and shareholder value. John Wiley \& Sons.

Firmansyah, N. (2020, May 27). Top 20 Food Influencer Di Indonesia. Retrieved Agustus 27, 2020, from starngage: https://starngage.com/top20-food-influencer-di-indonesia/

Jones, M. A., Mothersbaugh, D. L., \& Beatty, S. E. (2002). Why customers stay: measuring the underlying dimensions of services switching costs and managing their differential strategic outcomes. Journal of business research, 55(6), 441-450. 
Keller, K. L. (1993). Conceptualizing, measuring, and managing customer-based brand equity. Journal of marketing, 57(1), 1-22.

Keller, K. L. (2009). Building strong brands in a modern marketing communications environment. Journal of marketing communications, 15(2-3), 139-155.

Keller, K. L. (2012). Strategic Brand Management: Building, Measuring, and Managing Brand Equity 4th Edition. London, United Kingdom: Pearson.

Latiff, Z. A., \& Safiee, N. A. S. (2015). New business set up for branding strategies on social mediaInstagram. Procedia Computer Science, 72, 1323.

Liu, C., Zhang, Y., \& Zhang, J. (2020). The impact of self-congruity and virtual interactivity on online celebrity brand equity and fans' purchase intention. Journal of Product \& Brand Management, 29(6), 783-801,

Osorio, M. L., Centeno, E., \& Cambra-Fierro, J. (2020). A thematic exploration of human brands: literature review and agenda for future research. Journal of Product \& Brand Management, 29(6), 695-714.
Sab.id (2019, Oktober 21). Pengertian dari Selebgram, Paid Promote, Endorse, dan Influencer. Retrieved Agustus 28, 2020, from sab.id: https://www.sab.id/blog/pengertian-dari-selebgram-paid-promote-endorse-dan-influencer

Schiffman, L. G., Kanuk, L. L., \& Hansen, H. (2012). Consumer Behaviour 2nd ed. Pearson.

Sukhdial, A., Aiken, D., \& Kahle, L. (2002). Are You Old School?: A scale for measuring sports fans' old-school orientation. Journal of Advertising Research, 42(4), 71-81.

Thomson, M. (2006). Human brands: Investigating antecedents to consumers' strong attachments to celebrities. Journal of marketing, 70(3), 104-119.

Vitberg, A. (2010). Developing your personal brand equity. Journal of accountancy, 210(1), 42.

Watkins, B., \& Lee, J. W. (2016). Communicating brand identity on social media: A case study of the use of Instagram and Twitter for collegiate athletic branding. International Journal of Sport Communication, 9(4), 476-498.

Yoo, B., Donthu, N., \& Lee, S. (2000). An examination of selected marketing mix elements and brand equity. Journal of the academy of marketing science, 28(2), 195-211. 